\title{
DESIGN OF A TEST RIG FOR THE EXAMINATION OF MECHANICAL PROPERTIES OF ROLLING BEARINGS
}

\author{
Rafał JURECKI \\ Kielce University of Technology \\ Edward POKROPIŃSKI, Dariusz WIĘCKOWSKI, Łukasz ŻOŁĄDEK \\ Automotive Industry Institute
}

\begin{abstract}
:
The paper presents a design basis adopted for the construction of a test facility for the rig testing of rolling bearings. One of the methods of inspection of the bearings is the testing of the bearings as components having already been mounted in a specific machine component unit and tested in the conditions of operation of the unit as a whole. This article presents preliminary engineering requirements and the design of a special test rig for the examination of rolling bearings without the necessity of mounting the bearings in a specific machine component unit. The rig testing is widely used in consideration of numerous good points of such a method. The simulation testing of bearings (on test rigs) consists in reproducing as accurately as possible the real conditions of operation of the bearings when mounted in the device for which they are intended. The rigs used for such tests are complicated and expensive, but the results of such tests are more "reliable" and more accurately represent the impact of various operational factors (loads) on the durability of the bearings under test.
\end{abstract}

Key words: rolling bearings, rig tests, designing of test rigs

\section{INTRODUCTION}

Bearings $[1,2,6,9]$ are the machine parts that support shafts and axles or movable elements mounted on them. They are intended for transmitting the forces that act on the machine components supported by the bearings onto the machine body (housing, frame, etc.) and for reducing friction during the motion of journals relative to bearing housings. This paper deals with the rig testing of rolling bearings. a)

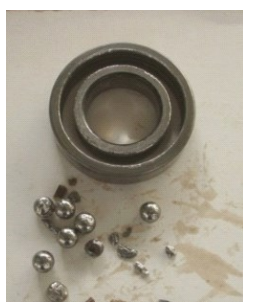

b)

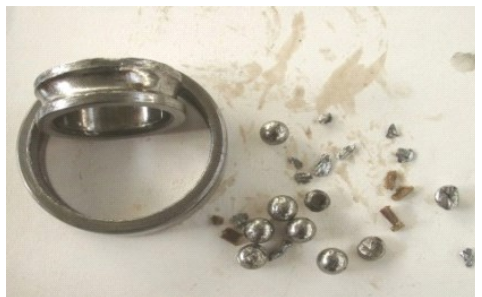

c)

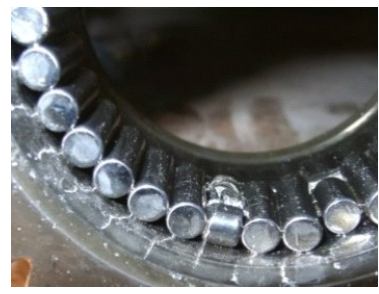

Fig. 1 Examples of damaged parts of rolling bearings:

$a$ - bearing balls damaged due to pitting, $b$ - inner ring raceway damaged due to pitting, $c$ - bearing rollers damaged due to pitting
The bearing materials should be characterized by such properties as:

- high seizure resistance,

- low coefficient of dry friction,

- high resistance to corrosion,

- high resistance to surface pressure at the working temperature,

- high fatigue strength,

- good thermal conductivity,

- good geometric stability,

- good workability.

Fig. 1 shows examples of damage to various parts of rolling bearings: a) balls; $b$ ) inner ring raceway; c) rollers.

One of the methods of inspection (examination) of the bearings is the testing of the bearings as parts having already been mounted in a specific machine component unit and tested in the conditions of operation appropriate for the unit as a whole.

\section{BASIC FEATURES AND PARAMETERS OF ROLLING BEAR- INGS}

The rolling bearings are characterized by intrinsic features and parameters that influence the selection of a bearing that would be appropriate for a specific application [4, $5,6,7,8,9]$. The basic parameters of a rolling bearing are: $\mathrm{d}$ - bore diameter,

D - outside diameter,

B or $\mathrm{T}-$ width of a radial or angular contact bearing, $\mathrm{H}$ - height of a thrust bearing, $r$ and $r_{1}$ - radius (or chamfer) between an end face and the adjoining cylindrical or conical mounting surface. 
The characteristic functional features of rolling bearings include quiet running, internal clearance, materials, and operating temperature. Apart from these, the following parameters related to the load-carrying capacity of the bearing are taken into account.

1. Basic static load rating, $C_{o}$ - applicable to the bearings whose rings rotate very slowly (with a speed of not more than $10 \mathrm{rpm}$; according to [8], this parameter may exclusively apply to the bearings whose rings do not move at all or rotate with a speed remaining within very narrow limits only) in relation to each other.

2. Basic static radial load rating, $C_{\text {or }}[8]$ - the static radial load which corresponds to a calculated contact stress at the centre of the most heavily loaded rolling element/ raceway contact of:

- $4600 \mathrm{MPa}$ for self-aligning ball bearings,

- $4200 \mathrm{MPa}$ for all other radial ball bearings types, and

- $4000 \mathrm{MPa}$ for all radial roller bearings.

3. Basic static axial load rating, $C_{o a}[8]$ - the static centric axial load which corresponds to a calculated contact stress at the centre of the most heavily loaded rolling element/raceway contact of:

- $4200 \mathrm{MPa}$ for thrust ball bearings, and

- $4000 \mathrm{MPa}$ for all thrust roller bearings.

4. Basic dynamic load rating, $\mathrm{C}$ - applicable to the bearings whose rings rotate in relation to each other (according to some sources, e.g. [4], only the inner ring rotates while the outer ring is stationary) and are subjected to a load. The basic dynamic load rating is the value, in newtons, of the load at which the bearing life would be one million revolutions.

5. Basic dynamic radial load rating, $C_{r}[8]$ - the radial load, constant in magnitude and direction, which a rolling bearing can endure for a basic rating life of one million revolutions.

6. Basic dynamic axial load rating, $C_{a}[8]$ - the centric axial load, constant in magnitude and direction, which a rolling bearing can endure for a basic rating life of one million revolutions.

The load ratings are specified in the product tables provided in rolling bearing catalogues. Apart from the above, equivalent bearing loads are considered [8]: static equivalent radial load, $\mathrm{P}_{\text {or }}$; static equivalent axial load, $\mathrm{P}_{\text {oa }}$; dynamic equivalent radial load, $P_{r}$; and dynamic equivalent axial load, $\mathrm{P}_{\mathrm{a}}$.

\section{BASIC PARAMETERS OF ROLLING BEARINGS}

\section{Life}

For an individual rolling bearing, life is the number of revolutions which one of the bearing rings makes in relation to the other ring before the first evidence of fatigue develops in the material of one of the rings or one of the rolling elements [8]. The bearing life may also be expressed as the time of bearing operation [h] at a specific rotational speed. The relation between the bearing life, dynamic load rating, and external load is described by a general formula:

where:

$$
L=\left(\frac{c}{p}\right)^{p}
$$

$\mathrm{L}-$ bearing life [million revolutions],

$C$ - dynamic load rating [daN],

$\mathrm{P}$ - equivalent bearing load [daN];

$\mathrm{P}$ - exponent of the life equation;

for ball bearings, $p=3$; for roller bearings, $p=10 / 3$.
For the machinery and equipment operating at a constant rotational speed, the bearing life is often expressed in hours of the bearing operation time $L_{h}[h]$, according to a formula:

$$
L_{h}=L * \frac{10^{6}}{n} * 60=\frac{16660}{n} *\left(\frac{c}{p}\right)^{p}[h]
$$

where:

$\mathrm{n}-$ bearing rotational speed $\left[\mathrm{min}^{-1}\right]$.

\section{Basic (conventional) rating life}

This is the rating life associated with $90 \%$ reliability for bearings manufactured with commonly used high quality material, of good manufacturing quality, and operating under conventional operating conditions [8]. The basic rating life is usually denoted by a symbol " $\mathrm{L}_{10}$ " and defined as follows:

$$
L_{10}=\left(\frac{c_{r}}{p_{r}}\right)^{p}
$$

for radial bearings and

$$
L_{10}=\left(\frac{c_{a}}{p_{a}}\right)^{p}
$$

for thrust bearings.

\section{Modified rating life, Lna}

This is the rating life obtained by adjusting the basic bearing rating life to the requisite reliability level, special material properties, and special operating conditions. In many cases, it is sufficient to determine the basic rating life $\mathrm{L}_{10}$ as a criterion that characterizes the bearing operation. The modified rating life $L_{n a}$ is the basic rating life modified for $(100-n) \%$ reliability of a bearing that has special properties and operates under unconventional operating conditions. It is defined by an equation:

$$
L_{n a}=a_{1} * a_{2} * a_{3} * L_{10}
$$

where:

$\mathrm{L}_{\text {na }}$ - adjusted rating life, with " $\mathrm{n}$ " representing the difference between the ideal $(100 \%)$ and requisite percentage bearing reliability and "a" indicating the method of calculation with the use of factors $a_{1}, a_{2}$, and $a_{3}$;

$a_{1}$ - reliability factor;

$a_{2}$ - material factor;

$a_{3}$ - operating conditions factor (chiefly depending on the lubrication and degree of contamination of the bearing system).

\section{Reliability}

The reliability of a single bearing is the probability that the bearing will attain or exceed a specified life [8].

\section{Limiting rotational speed}

The highest rotational speed permitted for a specific bearing is referred to as permissible rotational speed or limiting rotational speed $\mathrm{n}_{\mathrm{gr}}$.

\section{Acceptable rotational speed vs. bearing types}

The maximum rotational speed of rolling bearings varies depending not only on the bearing type but also on the bearing size, cage type, bearing loads, lubrication methods adopted, heat removal, etc. 


\section{TEST RIG DESIGN BASIS}

The basic reason for undertaking the construction of a test rig for the examination of rolling bearings was the need of checking such bearings without the necessity of mounting them in a specific machine component unit. The tests of this kind are aimed at verifying the quality of the bearings as structural elements to be built into various devices representing different levels of technological advancement. This makes it possible to acquire additional knowledge that would be useful to engineers in the machinery and equipment designing process so that not only a device could be built that would meet the objectives and requirements adopted but also the environmental impact of the device to be built would be taken into account [12].

\section{Basic technical specifications of the test rig}

The following requirements to be met by the test rig have been adopted:

- bearing system arrangement: rotating shaft (inner ring of the bearing) and stationary housing (outer ring of the bearing),

- rotational speed of the rotating (inner) ring of the bearing: max. $700-750 \mathrm{~min}^{-1}$; constant direction of rotation, either clockwise or counter-clockwise; however, the alternating direction of rotation is not planned,

- radial load on the bearing: maximum radial force 100 $\mathrm{kN}$, with only one sense of the force vector,

- axial load on the bearing: maximum axial force 100 $\mathrm{kN}$, with only one sense of the force vector,

- load application mode: the radial and axial loads to be applied separately or simultaneously, depending on the test conditions required.

Mechanical system

The test rig should be of modular design, making it possible to change the configuration of its components depending on needs. It should include the following major component units:

- Base,

- AC electric drive motor

- drive shaft (s),

- gearbox, installed optionally between the drive motor and the core test rig unit (module), i.e. a headstock, according to the test conditions adopted,

- core test rig unit (headstock), which is to take the radial and axial test loads from the bearing under test,

- replaceable flanged hub units, attached to the core test rig unit (headstock), intended for the mounting of the bearings to be tested in the rotating shaft mode,

- set of housings for the bearings under test,

- headstock fastening brackets,

- brackets and supports for the bearing load application system,

- set of tie rods to hold the test rig brackets together.

\section{Electrohydraulic load application system}

This system is to include electrohydraulic actuators for applying radial and axial loads to the bearings under test as well as hydraulic pressure distributor unit, hydraulic power supply system, piping, and valves.

\section{Lubricating and cooling system}

The lubricating and cooling system, intended to ensure circulating lubrication and cooling of the test rig headstock bearings and the bearings under test as well as supportive external cooling of the test rig, is to consist of two separate circuits that would include hydraulic power supply units, piping, valves, and fans.

\section{Measuring and control system}

The measuring subsystem should ensure measurements of the following quantities:

- rotational speed of the bearing under test,

- radial force acting on the bearing under test,

- axial force acting on the bearing under test,

- temperature of the oil lubricating the bearing under test and the core test rig unit, i.e. the headstock (temperature of the bearing under test and the headstock),

- parameters of vibration of the bearing under test (optional),

- time.

The control subsystem should ensure controlling of the test rig in compliance with a predefined test program in respect of the following:

- rotational speed of the headstock,

- radial force acting on the bearing under test,

- axial force acting on the bearing under test,

- temperature of the oil lubricating the bearing under test and the core test rig unit, i.e. the headstock (temperature of the bearing under test and the headstock),

- parameters of vibration of the bearing under test (optional)

- time of duration of the test program and its individual segments.

The measuring and control system as a whole should:

- ensure automated supervision of the operation of the test rig and the bearings under test,

- react to any faults or malfunctions in the system, by signalling the alarm conditions and switching the test rig off.

\section{Data acquisition}

The data acquisition system should enable the real-time recording of the time histories of selected physical quantities with a preset sampling frequency and length of the measuring time as well as the visualization and readout of the values having been measured.

\section{DESIGN OF THE TEST RIG}

\section{Mechanical layout}

The general mechanical layout of the test rig has been presented in Fig. 2. The test rig (and the object under test) is driven by $A C$ electric motor 1, through drive shaft with length compensation 2 . The core unit of the test rig is headstock 3, which takes the radial and axial test loads from the bearing under test 5 . The bearing under test is mounted on flanged hub 4 . The radial and axial test loads with only one sense of each of the force vectors $\left(P_{r}\right.$ and $P_{a}$, respectively) are applied by electrohydraulic actuators 6 and 7, respectively.

The test rig headstock consists of shaft supported by bearings, housing, and housing covers with seals. It is fixed between two brackets fastened to the test rig base. The 
R. JURECKI, E. POKROPIŃSKI, D. WIĘCKOWSKI, Ł. ŻOŁĄDEK - Design of a test ring for the examination of mechanical properties...

headstock shaft is to transmit the radial and axial loads applied to the bearing under test and the test rig driving torque. It is supported by two bearings mounted in the headstock housing.

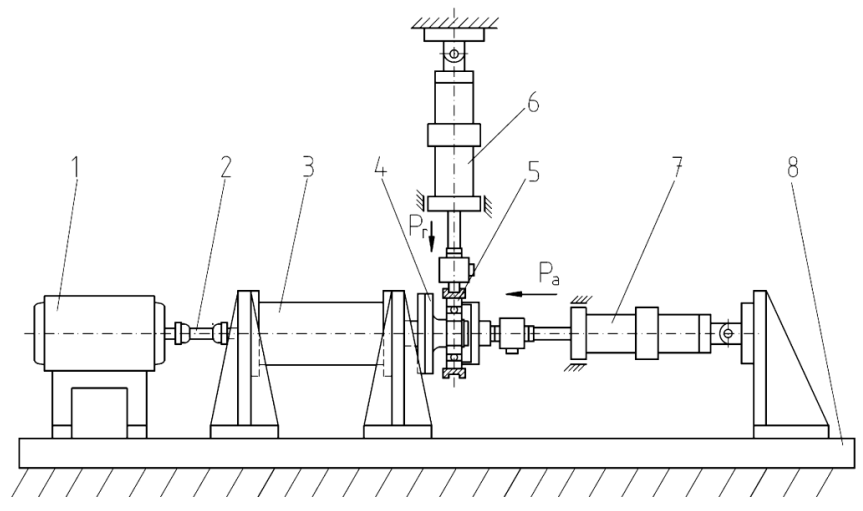

Fig. 2 General layout of the test rig:

1 - electric motor, 2 - drive shaft, 3 - headstock, 4 - flanged hub for the mounting of the bearing under test, 5 - bearing under test, 6 - radial load actuator, 7 - axial load actuator, 8 - test rig base, $\mathrm{Pr}$ - radial loading force, $\mathrm{Pa}$ - axial loading force

\section{PRELIMINARY ASSUMPTIONS}

- computational diagram of the headstock shaft,

- spacing of shaft supports (bearings) $\mathrm{A}$ and $\mathrm{B}: \mathrm{I}_{\mathrm{a}}=$ $0.680 \mathrm{~m}$,

- length of the cantilever part of the shaft: $I_{b}=0.320 \mathrm{~m}$,

- external load on the shaft (active forces): radial force applied as a load to the bearing under test: $F_{r}=100$ kN max.; the axial force applied as a load to the bearing under test, equal to $F_{a}=100 \mathrm{kN}$ max., has been disregarded in the analysis because it is to be transmitted by bearing $B$,
- torque transmitted by the shaft: the torque arising from the resistance to rotation in the bearing under test, headstock bearings, and seals has been disregarded in the analysis because of its low share in the total shaft load,

- changes in the direction of shaft rotation: possible at various types of the tests to be carried out on the test rig; however, any alternating torsional loads are not planned,

- shaft material: steel $40 \mathrm{H}$, quenched and tempered.

The longitudinal cross-section of the headstock has been shown in Fig. 3.

\section{MOUNTING UNIT FOR THE BEARING UNDER TEST}

This unit should ensure that the conditions of mounting the bearings under test should be in conformity with the mounting guidelines given in bearing catalogues. It has been assumed that the unit will consist of two basic components:

- flanged hub attached to the headstock shaft, with a journal to receive the inner ring of the bearing under test,

- bearing housing.

An example of the construction of this unit has been presented in Fig. 4.

\section{TEST RIG DRIVE SYSTEM}

For the electric drive motor to be selected, the frictional moments of the headstock bearings, bearings under test, and seals were estimated. It has been assumed that the drive motor torque should be 2.5-3 times as high as the maximum estimated value of the total moment of the system resistance to motion and that the attainable working speed of the motor should be as specified in the section "Basic technical specifications of the test rig". The resistance of the test rig to motion was estimated as described below $[3,5,10,11]$.

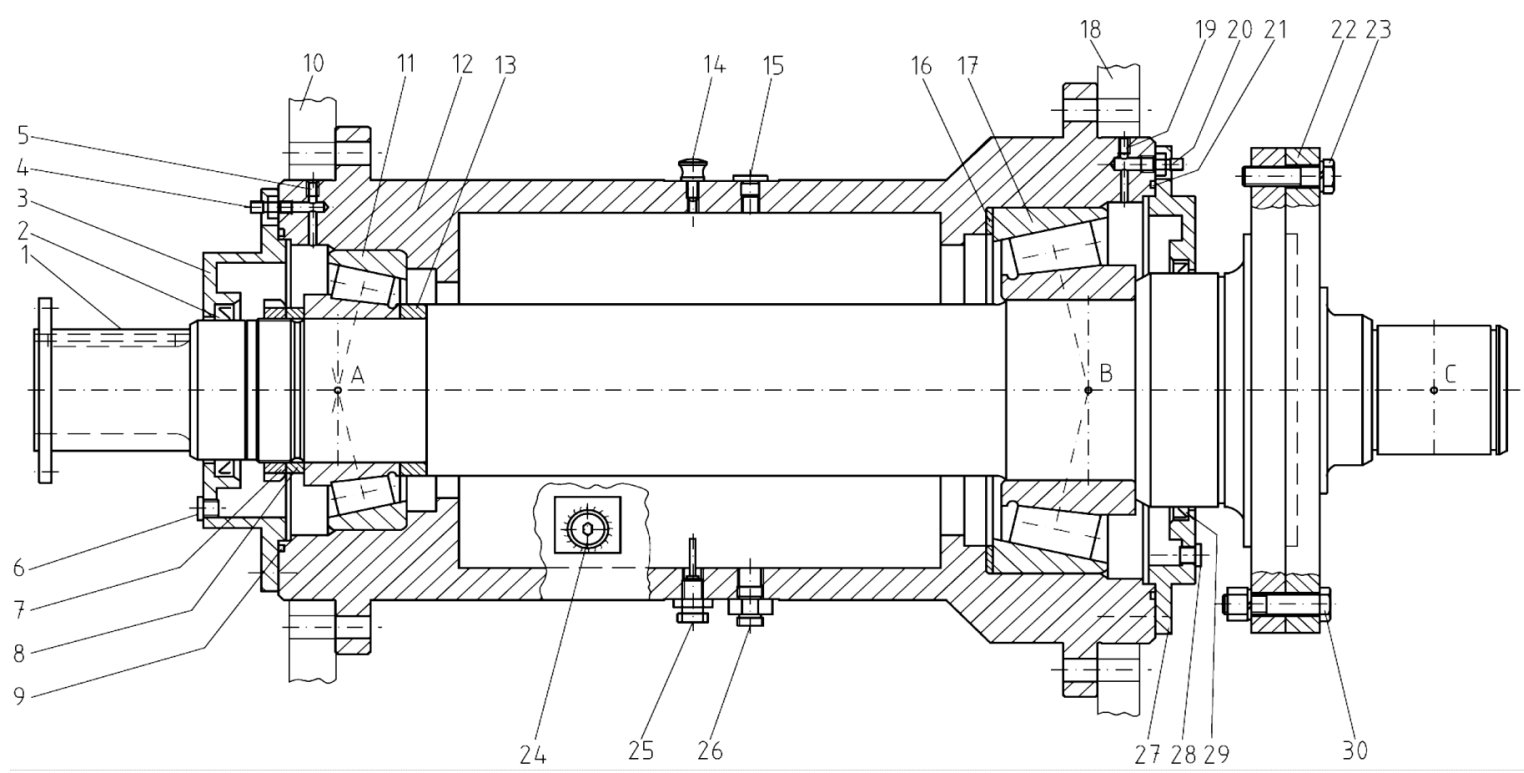

Fig. 3 Headstock - general construction, vertical longitudinal cross-section:

1 - input hub, 2 - sealing ring, 3 - headstock cover, bearing A side, 4, 20 - lube oil inlet port (hydraulic connection), 5, 19 - oil duct plug, 6, 28 - oil drain plug, 7 - bearing nut with a washer, 8 - spacer ring, 9 - sealing ring, 10 - headstock bracket $A$, 11 - headstock bearing A, 12 - headstock housing, 13 -spacer ring (for bearing preload or clearance adjustment), 14 -air bleeder, 15 -oil inlet plug, 16 - shims (for bearing preload or clearance adjustment), 17 - headstock bearing B, 18 - headstock bracket B, 21 - sealing ring, 22 - flanged hub with a journal to receive the bearings under test, 23 - screw, 24 - oil level control plug, 25 - temperature sensor, 26 - lube oil outlet port (hydraulic connection), 27 - headstock cover, bearing B side, 29 - sealing ring, 30 - bolt with a nut (alternative to 23), A, B, C-theoretical points of application of radial loads 


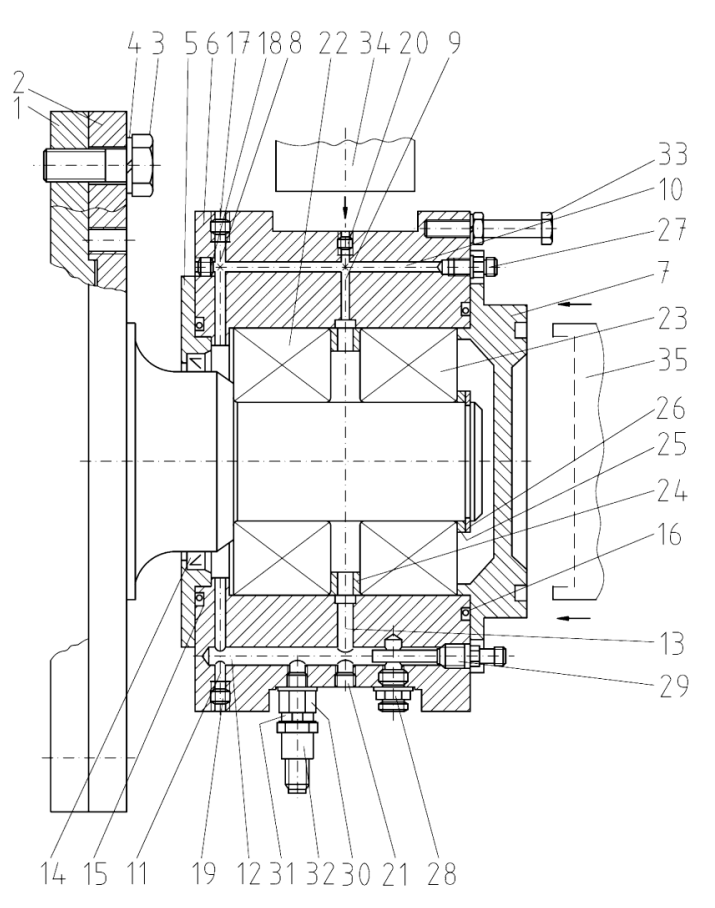

Fig. 4 Mounting and arrangement of the rolling bearings under test:

1 - test rig headstock shaft, 2 - flanged hub with a journal to receive the bearings under test, 3 - fastening screw, 4 - spring washer, 5 - inner cover of the housing of the bearings under test, 6 - housing of the bearings under test, 7 - outer cover of the housing of the bearings under test, 8, 9, 10, 11, 12, 13 lube oil ducts, 14 - sealing ring, 15 - O-ring seal, 17, 18, 19, 20, 21 - oil duct plug, 22, 23 - bearings under test, 24 - spacer sleeve between the bearings under test, 25 - spacer ring, 26 - retaining ring, 27 - lube oil inlet port (hydraulic connection), 28 - lube oil outlet port (hydraulic connection), 29 - oil temperature sensor, 30 - oil drain plug, 31 - vibration sensor foot, 32 - vibration sensor, 33 - lock screw to prevent the housing of the bearings under test from rotating, 34 - end adapter of the radial load actuator, 35 - end adapter of the axial load actuator

\section{RESISTANCE TO ROTATION IN THE HEADSTOCK BEARINGS}

The frictional moments of the bearings were calculated on the grounds of the following formula [11]:

$$
M=0.5 \mu P d
$$

where:

$\mathrm{M}-$ frictional moment $[\mathrm{Nm}]$,

$\mathrm{M}$ - constant coefficient of friction for the bearing,

$\mathrm{P}$ - equivalent dynamic bearing load $[\mathrm{N}]$,

$\mathrm{d}$ - bearing bore diameter $[\mathrm{mm}]$.

For the example bearing A (tapered roller bearing, designation HR32324J): $P=62.9 \mathrm{kN}=62900 \mathrm{~N}, d=120 \mathrm{~mm}$, $\mu=0.0018$, hence, $M_{A}=6.793 \mathrm{Nm}$.

For the example bearing $B$ (tapered roller bearing, designation 32332): $\mathrm{P}=375 \mathrm{kN}=375000 \mathrm{~N}, \mathrm{~d}=160 \mathrm{~mm}$, $\mu=0.0018$; hence, $M_{B}=54 \mathrm{Nm}$.

\section{RESISTANCE TO ROTATION IN THE BEARINGS UNDER TEST}

For the calculations, the maximum coefficient of friction $\mu=0.0024$ as for the angular contact double-row ball bearings and the maximum bearing bore diameter $d=80 \mathrm{~mm}$, according to the preliminary design specifications, have been adopted.
According to [5], the dynamic equivalent load is

$$
P=X F_{r}+Y F_{a}
$$

and, for the case under consideration, $\mathrm{e}=0.68$,

For $\left(F_{a} / F_{r}\right) \leq e, X=1$ and $Y=0.92$, while for $\left(F_{a} / F_{r}\right)>e$, $X=0.67$ and $Y=1.41$.

In this case, $\left(F_{a} / F_{r}\right)=100 / 100=1>e=0.68$; therefore, $X=0.67$ and $Y=1.41$. Hence, $P=208 \mathrm{kN}$.

The calculated value of the moment of the resistance to rotation in the bearings under test is $M_{B A D}=19.968 \mathrm{Nm}$.

Resistance to rotation in the headstock seals

The values of the resistance to rotation in the lip-type sealing rings (simmerrings) were estimated based on the data provided in [10].

The sealing ring on the bearing $A$ side: size $A$ $110 \times 140 \times 12$; for a shaft diameter of $110 \mathrm{~mm}$ and a rotational speed of $750 \mathrm{~min}^{-1}$, the power loss is $\Delta \mathrm{P}=80 \mathrm{~W}$ and the moment of the resistance to rotation is $M=1.019 \mathrm{Nm}$.

The sealing ring on the bearing $B$ side: size $A$ $210 \times 240 \times 15$; for a shaft diameter of $210 \mathrm{~mm}$ and a rotational speed of $750 \mathrm{~min}^{-1}$, the power loss is $\Delta \mathrm{P}=250 \mathrm{~W}$ and the moment of the resistance to rotation is $\mathrm{M}=3.183 \mathrm{Nm}$.

Resistance to rotation in the seals of the housing and journal of the bearings under test

The housing and journal sealing ring: size $A$ $110 \times 140 \times 12$; for a shaft diameter of $110 \mathrm{~mm}$ and a rotational speed of $750 \mathrm{~min}^{-1}$, the power loss is $\Delta \mathrm{P}=80 \mathrm{~W}$ and the moment of the resistance to rotation is $\mathrm{M}=1.019 \mathrm{Nm}$.

Total resistance to rotation in the bearings and seals

The moments of the resistance to rotation totalled at:

$\mathrm{M}_{\mathrm{op}}=6.793+54+19.968+1.019+3.183+1.019=$ $85.982 \mathrm{Nm}$; for the calculations, it has been adopted as $86 \mathrm{Nm}$.

Hence, the value of the power of the resistance to rotation with a rotational speed of $750 \mathrm{~min}^{-1}$ is Pop $=6.75 \mathrm{~kW}$.

Selection of the drive motor

Pursuant to the assumptions made, the output torque and power capacity of the drive motor should be 2.5-3 times as high as the maximum estimated corresponding values that represent the total resistance to rotation in the system bearings and seals. For the figures estimated as described above:

- the maximum torque should be $215-258 \mathrm{Nm}$;

- the maximum power capacity should be 17-20 kW.

The general design of the test rig has been outlined in Fig. 5 and 6.

\section{Lubricating system}

It has been assumed that this system should supply lube oil at a pressure of up to $0.4 \mathrm{MPa}$, with a delivery rate of up to $10 \mathrm{dm}^{3} / \mathrm{min}$, with stepless adjustment of the oil pressure and delivery rate. A schematic diagram of the lubricating system to be provided in the test rig under consideration has been presented in Fig. 7 .

\section{Electrohydraulic load application system}

The test rig is to be provided with an electrohydraulic system for the application of a radial and axial bearing loading force $\left(F_{r}\right.$ and $F_{a}$, respectively). In such a system, the energy is transmitted by a working fluid at a high pressure. 


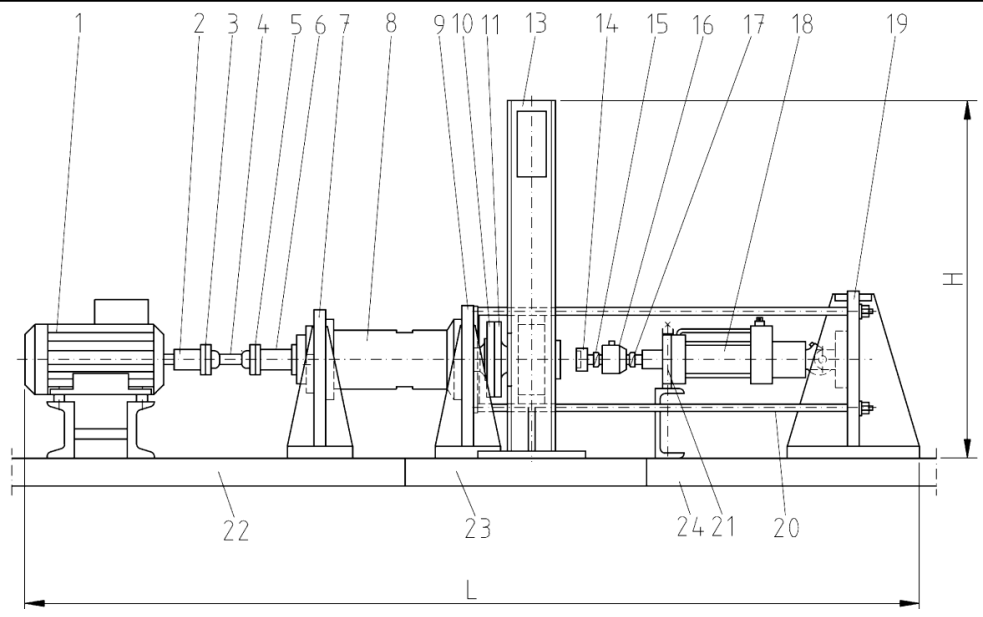

Fig. 5 Test rig - side view (general):

1 - electric drive motor; 2 - motor output hub; 3 -drive shaft adapter hub, motor end; 4 -drive shaft, 5 -drive shaft adapter hub, headstock end, 6 - headstock input hub, 7 - headstock fastening bracket A, 8 - headstock, 9 - headstock fastening bracket B, 10 - headstock shaft, 11 - flanged hub with a journal to receive the bearings under test, 12 - housing of the bearings under test, 13 - vertical (radial) actuator load frame D, 14 - end adapter of the horizontal (axial) load actuator, 15 - spiral spring washers, 16 - load cell (force transducer), 17 - spiral spring washers, 18 - horizontal (axial) actuator, 19 - horizontal (axial) actuator bracket $C$, 20 - tie rod to hold brackets $B$ and $C$ together, 4 units, 21 - horizontal (axial) actuator support, 22, 23, and 24 - bedplates used as the test rig base $(\mathrm{L}=3730 \mathrm{~mm}, \mathrm{H}=1920 \mathrm{~mm})$

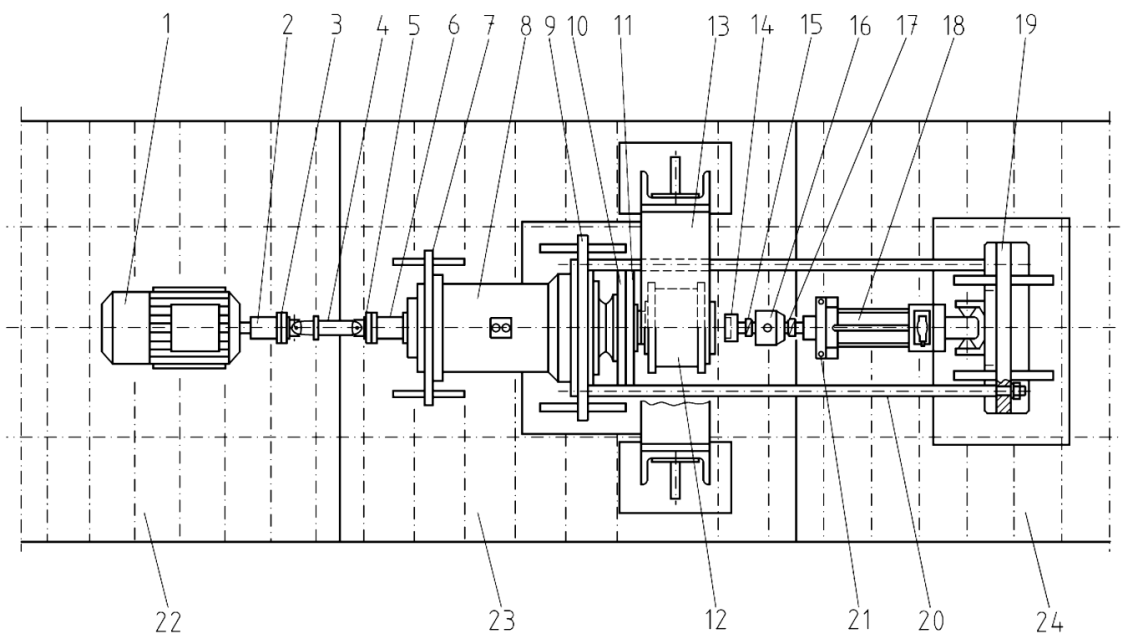

Fig. 6 Test rig - top view (general)

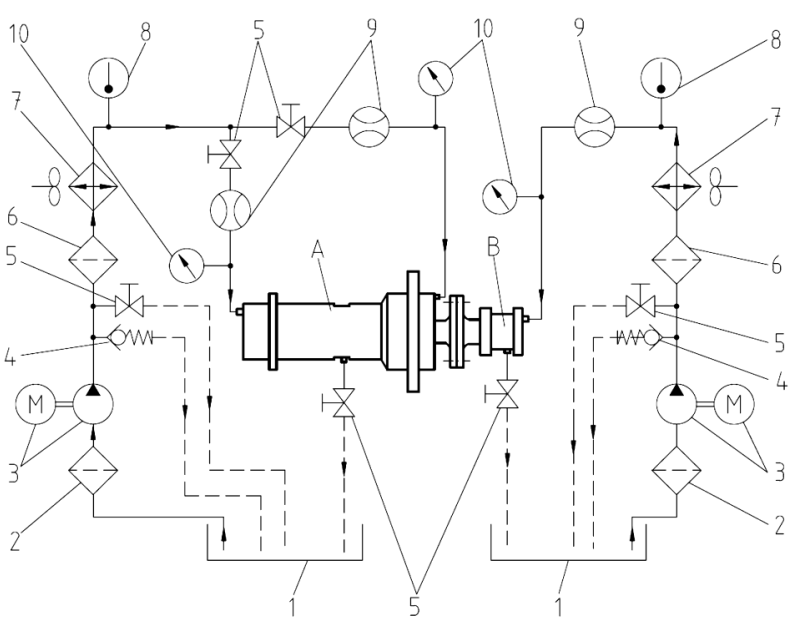

Fig. 7 Schematic diagram of the system to lubricate the headstock bearings and the bearings under test:

$A$ - headstock, B - housing of the bearings under test, 1 - lube oil tank, 2 - oil prefilter, 3 -oil pump and electric motor assembly, 4 - check valve, 5 - adjustment valve, 6 - fine oil filter, 7-oil cooler, 8 - thermometer, 9 - oil flowmeter, 10 -pressure gauge

\section{RECAPITULATION}

The paper presents preliminary technical specifications and a design concept of a test facility for the rig testing of rolling bearings. The test rig concept proposed is characterized by the following features:

1. Possibility of operation in both manual and automatic control mode, thanks to which the test may be carried out in accordance with specific needs and requirements.

2. Repeatability of test conditions and procedures.

3. Possibility of preparing, applying, and using complex control algorithms as well as implementing (according to the specific job or research task) special algorithms modified without the necessity of changing the basic configuration and layout of the test rig.

4. Easy acquisition of the measurement data.

5. Saving of individual measurement configurations in the test rig computer system (creation of libraries of readyto-use test "scenarios").

6. Possibility of modernization and development of the test rig. 


\section{REFERENCES}

[1] Z. Jaśkiewicz. Łożyskowania toczne w pojazdach mechanicznych, Wydawnictwa Naukowo-Techniczne, Warszawa, 1971.

[2] W. Korewa, and K. Zygmunt. Podstawy konstrukcji maszyn, część 2, $4^{\text {th }}$ ed., Wydawnictwa NaukowoTechniczne, Warszawa, 1973.

[3] L.W. Kurmaz. Podstawy konstrukcji maszyn. Projektowanie, Wydawnictwo Naukowe PWN, Warszawa, 1999.

[4] Łożyska toczne - dobór i obliczenia, http:// pkm.edu.pl/; http://bearings.webpassion.pl/; http://ezipk.ia.

[5] MOTION\&CONTROL ${ }^{\mathrm{TM}}$ NSK Łożyska toczne. Katalog Nr E 1102f.pdf @NSK Ltd. 2005. www.wama.com.pl/ upload/pliki/LOZYSKA_TOCZNE_CALOSC.pdf.

[6] Łożysko (mechanika) https://pl.wikipedia.org/wiki/\% C5\%810\%C5\%BCysko_(mechanika).
[7] PN-ISO 15:2002: Łożyska toczne. Łożyska poprzeczne. Wymiary główne, układ ogólny, 2002.

[8] PN-ISO 281:1994: Łożyska toczne. Nośność dynamiczna i trwałość, 1994.

[9] B. Reymer. [ed.]: Mały Poradnik Mechanika, Vol. 2: Podstawy konstrukcji maszyn. Maszynoznawstwo, Wydawnictwa Naukowo-Techniczne, Warszawa, 1994.

[10] Simrit: Simmerings and Rotary Seals. Freundenberg Simrit GmbH \& Co. KG/Technical Manual, 2007.

[11] SKF rolling bearings catalogue. CSKF Group 2013 www.skf.com/binary/77-121486/SKF-rolling-bearingscatalogue.pdf.

[12] A.N. Wieczorek. Designing machinery and equipment in accordance with the principle of sustainable development. in Management Systems in Production Engineering, Vol. 17, No. 1, 2015, pp. 28-34. DOI: 10.12914/MSPE-05-01-2015

dr inż. Rafał Jurecki

Kielce University of Technology

Al. 1000-lecia Państwa Polskiego 7, 25-314 Kielce, POLAND

e-mail: r.jurecki@tu.kielce.pl

mgr inż. Edward Pokropiński, dr hab. inż. prof. nzw. Dariusz Więckowski

mgr inż. Łukasz Żołądek

Automotive Industry Institute

ul. Jagiellońska 55, 03-301 Warszawa, POLAND

e-mail: e.pokropinski@pimot.eu

d.wieckowski@pimot.eu

I.zolodek@pimot.eu

The article in Polish language version available on the website of the journal 